\title{
Pituitary Receptors during Development in the Rat. I. TRH Binding Capacity
}

\author{
J. H. DUSSAULT ${ }^{(24)}$ AND P. COULOMBE \\ Laboratoire de Recherche en Endocrinologie-Métabolisme, Le Centre Hospitalier de l'Université Laval, 2705, Boul. \\ Laurier, Ste-Foy, Quebec, G1V 4G2, Canada
}

\begin{abstract}
Summary
In order to study the role of thyroid releasing hormone (TRH) in the control of thyroid stimulating hormone (TSH) secretion during the neonatal period, we measured the binding of $\left[{ }^{3} \mathrm{H}\right]-\mathrm{TRH}$ to pituitary homogenate of rats at various stages of development. In 2-day-old animals, the number of $\left[{ }^{3} \mathrm{H}\right]$-TRH binding sites were similar to that of adult male animals $(23 \pm 8 \mathrm{fmole} / \mathrm{mg}$ protein versus $21 \pm 7$ fmole/mg protein, respectively). Between 5-21 days of age, the number of $\left[{ }^{3} \mathrm{H}\right]$-TRH binding sites was significantly higher than that of adult animals $(P<0.01)$. Hypothyroidism induced a 2 -fold increase in the number of $\left[{ }^{3} \mathrm{H}\right]$-TRH binding sites in all the age groups studied. This effect was reversed by administration of $L-T_{4}(0.4 \mu \mathrm{g} / \mathrm{g}$ body weight for 3 days). These studies thus indicate that TRH binding sites are present during the neonatal period in the rat and suggest that TRH may be an important modulator of TSH secretion during this period in the rat and that these effects are mediated by postreceptor mechanisms.
\end{abstract}

\section{Abbreviations}

CMC, carboxy methyl cellulose

$\mathbf{G H}_{3}$, growth hormone

PTU, propylthiouracil

TRH, thyroid releasing hormone

TSH, thyroid stimulating hormone

The hypothalamo-pituitary-thyroid axis develops postnatally in the rat (11). Hypothalamic TRH concentrations as well as pituitary and serum TSH levels increase gradually after birth and reach adult values by the second wk of postnatal life. In the rat, the secretion of TSH is dependent upon the release of the hypothalamic hormone TRH. TRH binds to specific receptor sites on the external surface of the plasma membrane of thyrotrophs and/or mammatrophs and activates adenylyl cyclase with elevation of intracellular levels of cyclic AMP leading to the activation of protein kinase, phosphorylation of protein substrates and modifications in the secretion of TSH and prolactin (16). TRH receptor sites have now been characterized in bovine and rat pituitary gland $(7,16)$, as well as in thyrotropic-pituitary tumor cells $(19)$.

Previous experiments have shown that in the adult animal, the level of pituitary TRH receptor is modulated by both estrogens and thyroid hormones (7). Hypothyroidism induces a significant increase in the number of TRH receptors, whereas administration of thyroid hormones leads to a progressive decline in the levels of TRH receptors (7). Previous experiments have suggested that TRH was not the modulator of TSH secretion during the neonatal period. Tonooka et al. (21) reported that serum TSH concentrations in encephalectomized fetus was markedly elevated when pregnant rats were fed PTU and that hypothalamic lesions in these PTU-fed pregnant rats did not prevent the TSH rise in the fetus. Theodoropoulos et al. (20) treated neonatal hypothyroid rats with TRH antiserum and found that this treatment was ineffective in decreasing serum TSH concentrations before the tenth day of life. We have recently observed that exogenous administration of TRH during the neonatal period leads to a significant increase in serum TSH concentration, which can be impaired in a dose-dependent fashion by treatment of the neonatal rat with $\mathrm{T}_{3}(22)$.

In order to clarify the possible role of TRH in the control of TSH secretion, we measured the binding capacity of pituitary membrane bound TRH receptors during development as well as the effects of thyroid hormone in the control of the number of TRH receptor. The results of these experiments are presented in this communication.

\section{MATERIALS AND METHODS}

Animals. Virgin Sprague-Dawley rats were mated at the supply house (Canadian Breeding Farms, St-Constant, Laprairie, Canada) and shipped to the vivarium on the sixteenth day of pregnancy. Pregnant rats were maintained in single cages on bedding of wood shavings in a sound-attenuated, temperature- and lightcontrolled (14 h of light) room. Humidity was not controlled. All animals had free access to water and rat laboratory chow.

$\left[{ }^{3} H\right]-T R H$ binding assay. $\left[{ }^{3} \mathrm{H}\right]-\mathrm{TRH}$ binding was measured according to the method described by DeLean et al. (7). After sacrifice, pituitaries $(\sim 12 \mathrm{mg}$ tissue $)$ were homogenized in 15 volume of cold TKM buffer ( $40 \mathrm{mM}$ Tris, $\mathrm{pH}=7.4,7.5 \mathrm{mM}$ $\mathrm{KCL}, 2 \mathrm{mM} \mathrm{MgCl}_{2}$ ) using a small Teflon glass homogenizer (Kontes). For the binding assay, $0.030 \mathrm{ml}$ of pituitary homogenate and $0.050 \mathrm{ml}$ of $\left[{ }^{3} \mathrm{H}\right]-\mathrm{TRH}$ (New England Nuclear Co, $\mathrm{L}-\left[2,3,{ }^{3} \mathrm{H}\right]$ -proline labeled, $100 \mathrm{Ci} / \mathrm{mmole}$ ) (final concentration $=50 \times 10^{-9}$ $M)$ were incubated in the presence or in absence of 100 -fold excess of cold TRH. Incubations were carried out at $0^{\circ} \mathrm{C}$ for a period of $60 \mathrm{~min}$. At the end of the incubation period, $2 \mathrm{ml}$ of cold TKM buffer was added to each tube and the bound fraction was separated by suction through cellulose nitrate filter (pore sizè, 0.45 microns) and rinsed 3 times with $2 \mathrm{ml}$ of cold buffer. Filter were then allowed to dry in scintillation vials and $10 \mathrm{ml}$ of Aquasol (New England Nuclear) was added to each sample. Radioactivity was counted for $10 \mathrm{~min}$ in a LKB scintillation counter at a $95 \%$ counting efficiency. All experiments were carried out in duplicate. In some experiments, anterior pituitaries from adult animals were pooled for detailed analysis of binding affinity and number of binding sites. The binding capacity is expressed as fmoles of $\left[{ }^{3} \mathrm{H}\right]$ -TRH bound/mg protein. Membrane proteins were measured by the method of Lowry et al. (17) using bovine serum albumin as standard.

Developmental study of pituitary TRH receptor. $\left[{ }^{3} \mathrm{H}\right]-\mathrm{TRH}$ binding sites were measured in 2-, 5-, 9-, 11-, 14-, 21-, 30-, 50-day-old rats and in adult animals. $\left[{ }^{3} \mathrm{H}\right]$-TRH binding capacity was measured as described above. Before 14 days of age, pituitaries from male and female animals were pooled because we did not find any significant effect of sex on the number of $\left[{ }^{3} \mathrm{H}\right]-\mathrm{TRH}$ binding sites. From 21 days on, only male animals were used for the study of binding capacity. 
Regulation of pituitary TRH receptor by thyroid hormones. Hypothyroidism was induced in adult rats by feeding them with $6-\mathrm{N}$ propyothiouracil (PTU) $(0.05 \%)$ in their drinking water for a period of at least 2 months. On the other hand, neonatal hypothy-

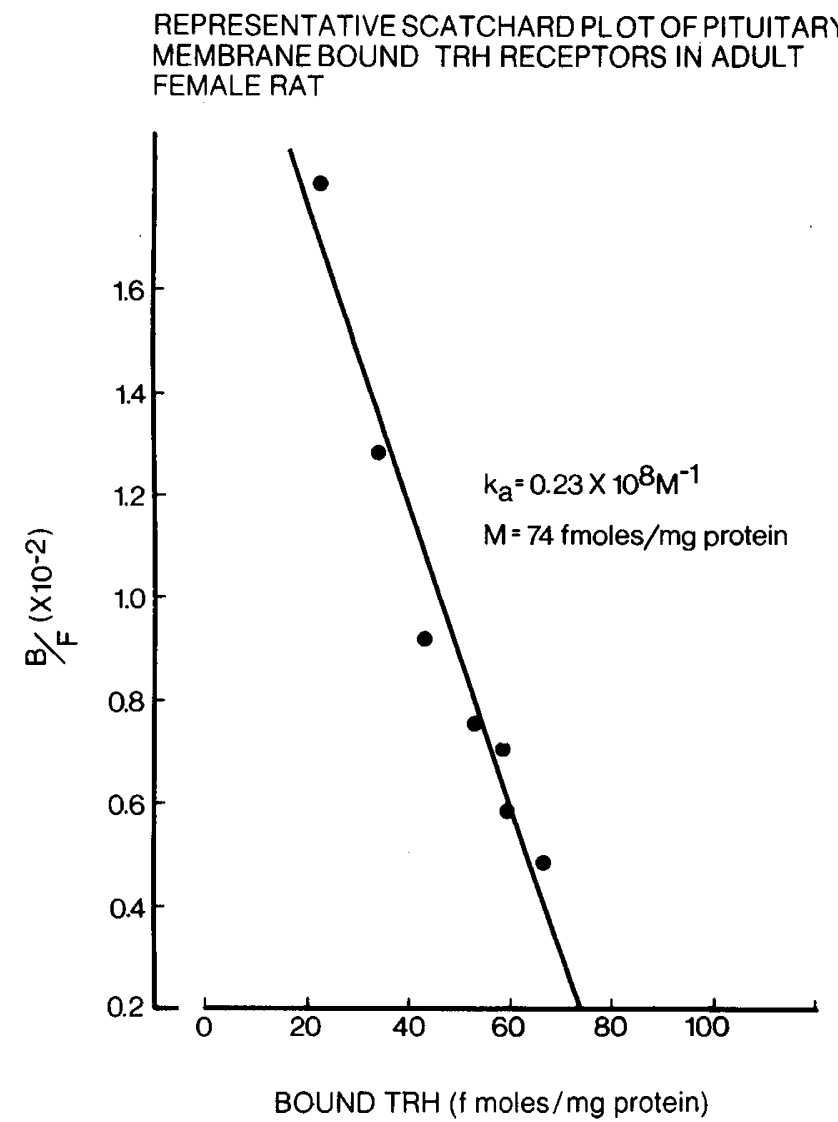

Fig. 1. Representative Scatchard plot of pituitary membrane bound thyroid releasing hormone (TRH) receptors in adult female rat. The binding capacity was determined as described in the "Materials and Methods" section.

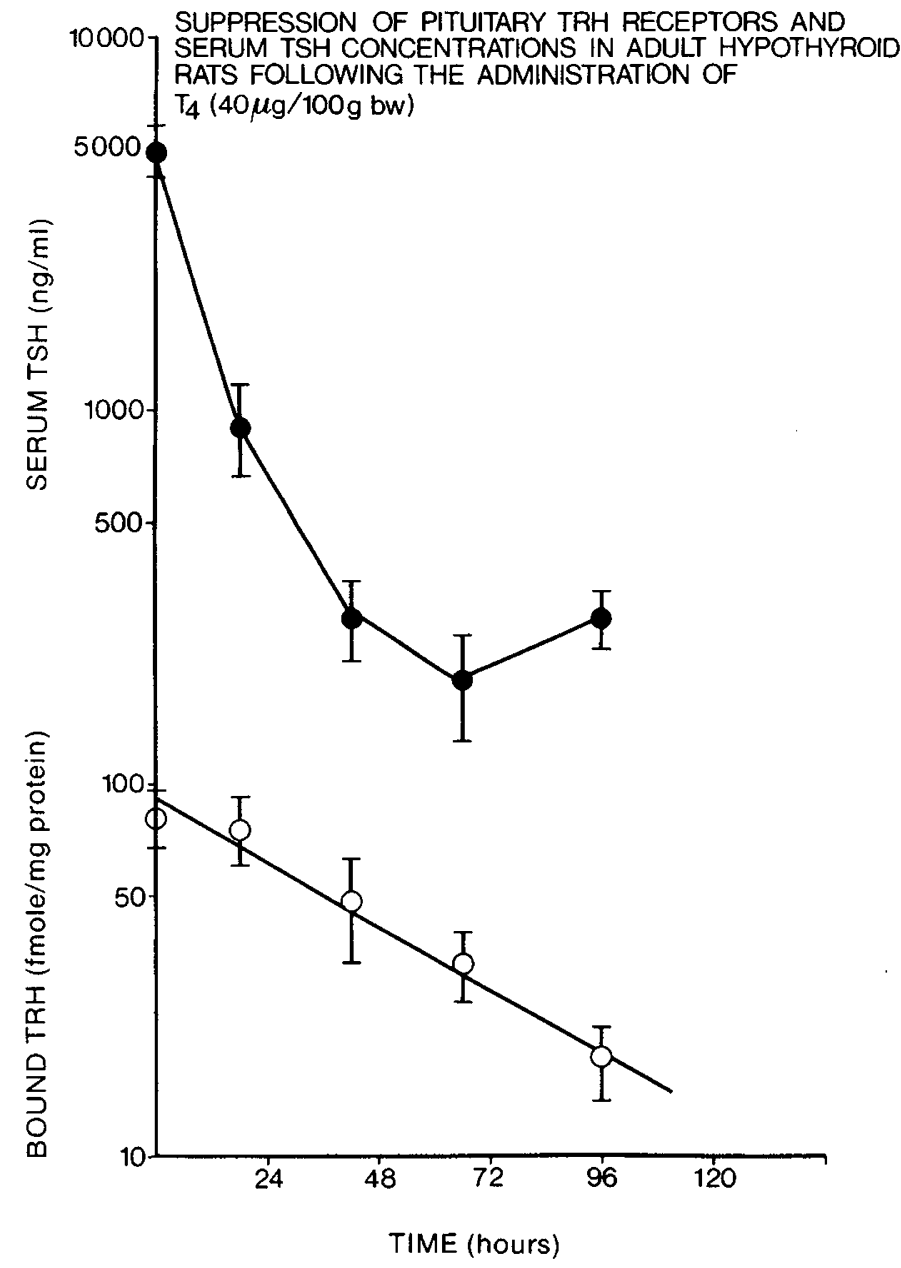

Fig. 3. Suppression of pituitary thyroid releasing hormone (TRH) receptors and serum thyroid stimulating hormone (TSH) concentrations in adult hypothyroid rats. The animals were received a daily injection of $T_{4}$ and were sacrificed at the indicated time. Results are expressed as the mean \pm S.E.

ONTOGENESIS OF PITUITARY TRH RECEPTORS IN THE POSTNATAL RAT

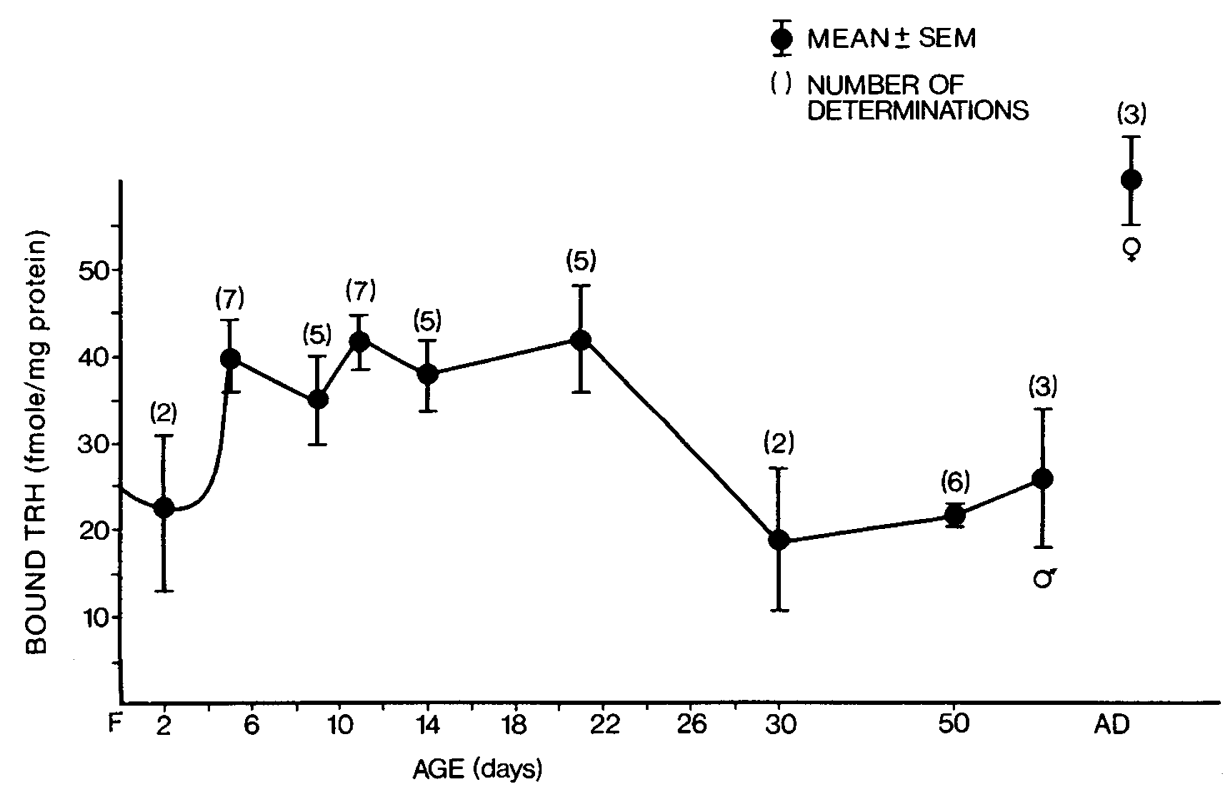

Fig. 2. Ontogenesis of pituitary thyroid releasing hormone (TRH) receptors in the rat. Bound TRH was determined as described in the "Materials and Methods" section. Each point comprises the mean \pm S.E. The number in parenthesis refers to the number of determination. The level of TRH receptors between day 5 and 22 are significantly different than the day 2 levels and adult level by contrast analysis $(P<0.01)$. 
roidism was induced by feeding the pregnant female rat with similar PTU solution beginning on the fourteenth day of gestation. The day of birth, the PTU solution was replaced by tap water and the newborn animals were injected daily with $100 \mu \mathrm{g}$ PTU in $1 \%$ CMC (carboxy methyl cellulose). This procedure ensures normal lactation.

The effect of thyroid hormones on the pituitary $\mathrm{TRH}$ receptors was studied by injecting adult hypothyroid rats with $T_{4}(40 \mu \mathrm{g} /$ $100 \mathrm{~g}$ body weight) (Sigma Co.) for a period varying from 1-4 days. Neonatal hypothyroid animals were treated with $\mathrm{T}_{4}(40 \mu \mathrm{g} /$ $100 \mathrm{~g}$ body weight) for 3 consecutive days and the levels of TRH receptors were measured $24 \mathrm{~h}$ after the last $T_{4}$ injection.

Hormone assays. Serum $\mathrm{T}_{4}$ and $\mathrm{T}_{3}$ concentrations were measured by specific double antibodies radioimmunoassays $(4,5)$. Serum TSH concentration was measured using TSH Kits provided by Dr. A. F. Parlow on behalf of the Rat Pituitary Hormone Distribution Program of the NIAMMD. All samples within an experiment were measured in duplicate in the same RIA run.

Statistical and analysis. Statistical analysis was performed by analysis of variance or by Student $t$ test, or contrasts analysis.

\section{RESULTS}

Figure 1 illustrates a representative Scatchard plot in pituitary homogenate from adult female animal. A single class of binding sites with an association constant (Ka) is $0.23 \times 10^{8} \mathrm{M}^{-1}$ and a binding capacity of $74 \mathrm{fmole} / \mathrm{mg}$ protein is observed. Figure 2 illustrates the developmental pattern of pituitary TRH receptor in the rat. Between 2-5 days, the number of TRH receptors increase from $23 \pm 8 \mathrm{fmole} / \mathrm{mg}$ protein to $39 \pm 5 \mathrm{fmole} / \mathrm{mg}$ protein. The number of TRH receptors remains stable until weaning after which it falls significantly towards adult values $(21 \pm 7 \mathrm{fmole} / \mathrm{mg}$ protein. These values are significantly different at the $1 \%$ level by contrasts analysis.
Figure 3 illustrates the effects of hypothyroidism and daily administration of $\mathrm{T}_{4}(40 \mu \mathrm{g} / 100 \mathrm{~g}$ body weight $)$ on both serum TSH concentration and pituitary TRH receptor content. Serum TSH concentration as well as pituitary TRH receptor were significantly elevated $(5000 \pm 200 \mathrm{ng} / \mathrm{ml}, 95 \pm 3 \mathrm{fmole} / \mathrm{mg}$ protein, respectively) in hypothyroid animals. Daily adminstration of $T_{4}$ resulted in a time dependent decrease in both serum TSH and pituitary receptor concentration. The number of TRH binding sites decreased with a T1/2 of $42 \mathrm{~h}$. At that time, serum TSH concentration was within the normal range $(300-500 \mathrm{ng} / \mathrm{ml})$.

Figure 4 illustrates the regulation of pituitary TRH receptor by thyroid hormones. As early as 5 days of age, neonatal hypothyroidism induces a 2-fold increase in the number of TRH receptors $(70 \pm 10 \mathrm{fmole} / \mathrm{mg}$ protein versus $40 \pm 4 \mathrm{fmole} / \mathrm{mg}$ protein). Treatment with $\mathrm{T}_{4}(40 \mu \mathrm{g} / 100 \mathrm{~g}$ body weight) completely reversed the effects of hypothyroidism. As shown in figure, similar effects of hypothyroidism and $T_{4}$ therapy were observed throughout development.

\section{DISCUSSION}

In the rat, the functional integrity of the hypothalamo-pituitary axis does not occur before the fourth and fifth day of life and the development of the capillary tufts of the median eminence continue until 40 days of life $(6,13,23)$. It would thus appear that the participation of hypothalamic TRH in mediating the changes in TSH secretion is negligeable until the fifth day of life, although the hypothalamus synthesizes TRH molecules as early as 2 days of age (11).

Our data confirm the finding that in adult animal, thyroid hormones control the concentration of pituitary TRH receptors (7). Hypothyroidism results in an increase in the number of pituitary TRH receptors, which is reversed by the administration of $T_{4}$. Furthermore, as shown in figure 2, the time dependent

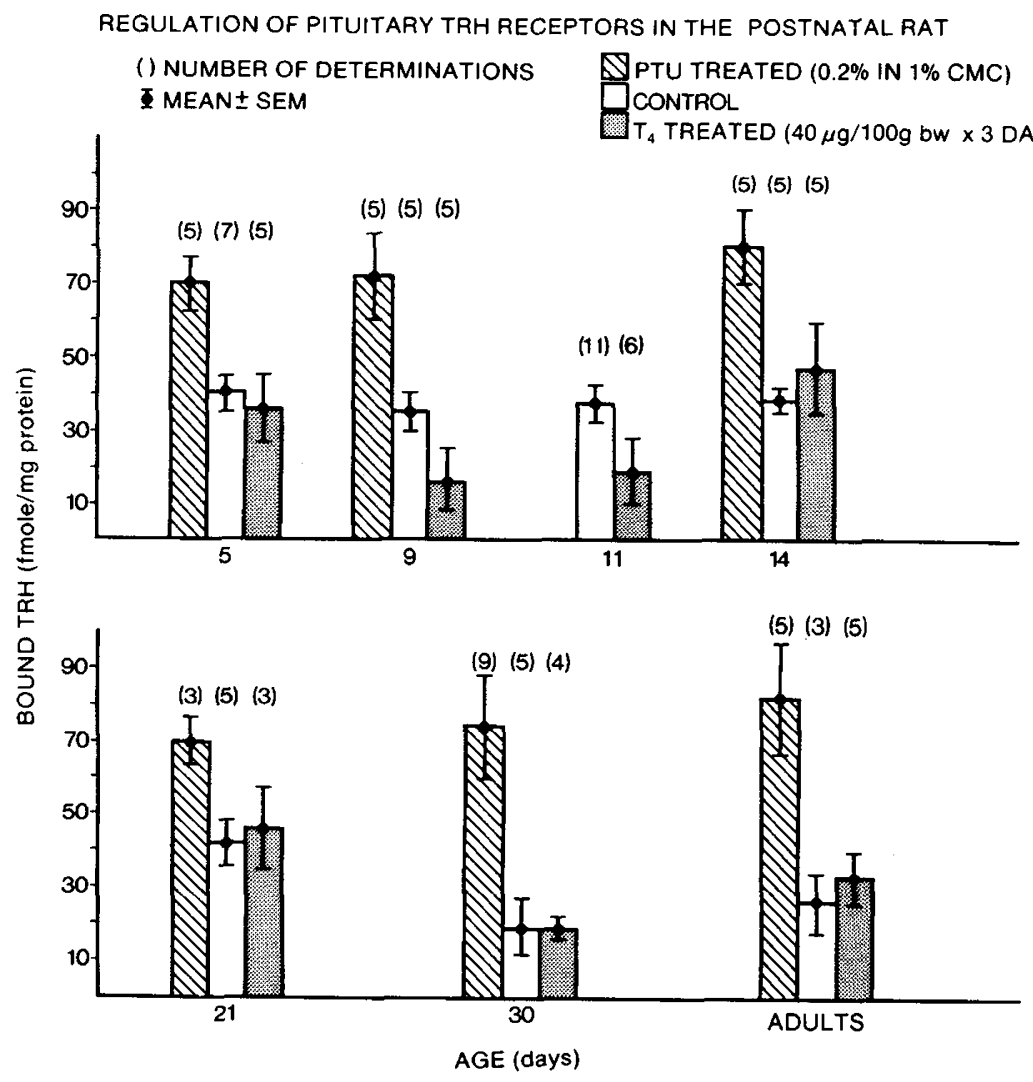

Fig. 4. Regulation of pituitary thyroid releasing hormone (TRH) receptors during the postnatal period in the rat. Hypothyroidism was induced neonatally by administration of propylthiouracil (PTU) $(0.2 \%$ in $1 \%$ carboxy methyl cellulose). The animals were sacrificed at the indicated age. Results are expressed as the mean \pm S.E. Treatment of hypothyroid rats with $\mathrm{T}_{4}(40 \mu \mathrm{g} / 100 \mathrm{~g}$ body weight). For all the age groups the levels of TRH receptors in the control animal and $\mathrm{T}_{4}$-treated animals are similar by significantly different from the PTU-treated animals using a Student $t$ test $(P<0.01)$. $\square$, control animals; $\mathbb{Z}$, PTU-treated animals; and $⿴ 囗 0)$, hypothyroid rats $+T_{4}(40 \mu \mathrm{g} / 100 \mathrm{~g}$ body weight) for 3 days. 
decrease in pituitary TRH receptor concentrations parallels the decrease in serum TSH secretion, confirming recent results in $\mathrm{GH}_{3}$ cells where Perrone and Hinkle (19) observed similar effects of hypothyroidism and $\mathrm{T}_{3}$ supplemented medium on TRH receptor concentration. In $\mathrm{GH}_{3}$ cells, TRH stimulates prolactin synthesis and this effect is inhibited by the addition of physiologic doses of $\mathrm{L}-\mathrm{T}_{3}$. Furthermore, TRH itself induces a 2-fold decrease in TRH receptor concentration which was additive with the effects of $T_{3}$. But in vivo, it is difficult to evaluate the effects of TRH on its own pituitary receptor. Dupont et al. (10) have recently shown that the concentration of TRH was not altered significantly in 31 discrete rat brain nuclei, but that it was significantly reduced in the median eminence of rats made hypothyroid at birth. Of interest was the finding that treatment of neonatal hypothyroid rats with replacement doses of $\mathrm{T}_{4}$ restored the TRH content in the median eminence to that of control animals. These findings would suggest that thyroid hormones play an important role at the hypothalamic level.

Our results indicate that the TRH receptor is present in significant amounts during the neonatal period and even during late fetal life (data not shown). Furthermore, the concentration of TRH receptor in 4-day-old rat is similar to that of adult animal. It is of interest to note that during the neonatal period, thyroid hormones regulate the number of TRH receptors. Indeed, as shown in Figure 4, hypothyroidism leads to a 2-fold increase in the number of TRH receptors, whereas administration of $T_{4}(0.4$ $\mu \mathrm{g} / \mathrm{g}$ body weight for 3 days) restores the receptor level to that of controls. These opposite effects were also observed in all the age groups studies.

There is still controversy over the control of TSH secretion during the neonatal period. Theodoropoulos et al. (20) recently presented data which suggest that TRH does not participate in TSH regulation during the first 10 days of postnatal life. Their results were primarily based on the lack of effect of TRH antiserum in suppressing fetal and neonatal TSH secretion. Using a similar framework, Oliver $e t$ al. (18) concluded that administration of TRH antiserum suppressed the TSH secretion in 5- and 7-dayold rats. In recent experiments, we have shown that in neonatal rats (5-day-old), TRH induces a dose-related increase in TSH secretion, which was greater than that observed in adult animal. Furthermore, this TRH induced-TSH release was inhibited in a dose dependent fashion by administration of $T_{3}(22)$. As TRH becomes available to the thyrotroph cells of the pituitary, TRH binds to its own TRH receptors and induces a liberation of TSH. In turn, thyroid hormones, $\mathrm{T}_{4}$ or $\mathrm{T}_{3}$ maintain the number of TRH receptors, presumably by binding to a class of nonhistone nucleoprotein, by a postreceptor mechanism involving the synthesis of unknown proteins $(2,12)$. Because it has been reported that binding to only a small fraction of the total population of cellular receptors is sufficient for full activation of adenyl cyclase (1), it is therefore possible that minute amount of TRH reaching the pituitary during the neonatal period might be sufficient to assure the control of TSH secretion. Clearly additional studies will be required to effectively measure the endogenous saturation of the TRH receptor during development.

\section{REFERENCES AND NOTES}

1. Birnbaumer, L. and Pohl, S. L.: Relation of glucagon-specific binding sites to glucagon-dependent stimulation of adenylyl-cyclase activity in plasma mem- branes of rat liver. J. Biol. Chem., 248: 2056 (1973).

2. Bowers, C. Y., Lee, K. L., and Schally, A. V.: A study of the interaction of the thyrotropin releasing factor and L-triiodothyronine: effects of puromycin and cycloheximide. Endocrinology, 82: 75 (1968).

3. Campbell, H. J.: The development of the primary portal plexus in the median eminence of the rabbit. J. Anat., 100: 318 (1966).

4. Chopra, I. J.: A rapid radioimmunoassay for the measurement of thyroxine in unextracted serum. J. Clin. Endocrinol. Metab., 34: 938 (1972).

5. Chopra, I. J., Ho, R. S., and Lam, R. W.: An improved radioimmunoassay for triiodothyronine in serum: its application to clinical and physiological studies. J. Lab. Clin. Med., 80: 729 (1972).

6. Daikuri, S., Kotsu, T., and Hashimoto, M.: Electron microscopic observations on the development of the Median eminence in perinatal rats. Z. Anat. Entwicklungsgesch, 134: 311 (1971).

7. DeLean, A., Ferland, L., Drouin, J., Felly, P. A., and Labrie, F.: Modulation of pituitary thyrotropin releasing hormone receptor leveis by estrogens and thyroid hormones. Endocrinology, 100: 1496 (1977).

8. Dixon, W. J., and Massey, F. J.: Introduction to statistical analysis, ed. 3, (McGraw-Hill, New York, 1969).

9. Drouin, J., DeLean, A., Rainville, D., Lachance, R., and Labrie, F.: Characteristics of the interaction between thyrotropin-releasing-hormone and somatostatin for thyrotropin and prolactin release. Endocrinology, 98: 514 (1976).

10. Dupont, A., Dussault, J. H., Rouleau, D., DiPaolo, T., Coulombe, P., Gagné, B. Ménard, Y., Moore, S., and Barden, N.: Effect of neonatal thyroid deficiency on the catecholamine, substance $P$, and thyrotropin-releasing-hormone content of discrete rat brain nuclei. Endocrinology, 108: 2039 (1981).

11. Dussault, J. H. and Labrie, F.: Development of the hypothalamic-pituitarythyroid axis in the neonatal rat. Endocrinology, 97: 1321 (1975).

12. Gard, T. G., Berstein, B., and Larsen, P. R.: Mechanism of $T_{3}$-induced inhibition of pituitary TSH release in vitro. Proc. American Thyroid Association, Abst. T27, 1980.

13. Glydon, St., R. J.: The development of the blood supply of the pituitary in the albino rat, with special reference to the portal vessels. J. Anat., 91: 237 (1957).

14. Grant, G., Vale, W., and Guillemin, R.: TRF and thyroid hormones on prolactin secretion by rat anterior pituitary cells in vitro. Endocrinology, 93: 26 (1973).

15. Hinkle, P. A., Perrone, M. H., and Schonbrunn, A.: Mechanism of thyroid hormone inhibition of thyrotropin-releasing-hormone action. Endocrinology, 108: 179 (1981)

16. Labrie, F., Barden, N., Poirier, G., and DeLean, A.: Characteristics of binding of $\left[{ }^{3} \mathrm{H}\right]$-thyrotropin-releasing hormone to plasma membranes of bovine anterior pituitary gland. Proc. Natl. Acad. Sci. U.S.A., 69: 238 (1972)

17. Lowry, O. H., Rosebrough, N. J., Farr, A. L., and Randall, R. J.: Protein measurement with the Folin phenol reagent. J. Biol. Chem., 193: 265 (1951)

18. Oliver, C., Giraud, P. Lissitzky, J. C., Conte-Devolx, B., and Gillioz, P.: Influence of thyrotropin-releasing-hormone on the secretion of thyrotropin-releasinghormone on the secretion of thyrotropin in neonatal rats. Endocrinology, 108 : 179 (1981).

19. Perrone, M. H., and Hinkle, P. M.: Regulation of pituitary receptors for thyrotropin-releasing hormone by thyroid hormones. J. Biol. Chem., 253: 5168 (1978).

20. Theodoropoulos, T., Braverman, L. E., and Vagenakis, A. G.: Thyrotropinreleasing-hormone is not required for thyrotropin secretion in the perinatal rat. J. Clin. Invest., 63: 588 (1979).

21. Tonooka, N. and Greer, M. A.: Evidence that control of fetal thyrotropin secretion is independent of both the fetal and maternal hypothalamus. Endocrinology, 102: 852 (1978).

22. Walker, P., Coulombe, P., and Dussault, J. H.: Effects of triiodothyronine on thyrotropin-releasing-hormone induced thyrotropin release in the neonatal rat. Endocrinology, 107: 1731 (1980).

23. Yoshimura, F., Harumia, K., and Kiyama, H.: Light and electron microscopic studies of the cytogenesis of anterior pituitary cells in perinatal rat in reference to the development of target organs. Arch. Histol. Japan, 31: 333 (1970).

24. Requests for reprints should be addressed to: Dr. Jean $H$. Dussault, Laboratoire de Recherche en Endocrinologie et Métabolisme, Le Centre Hospitalier de l'Université Laval, 2705 Boul. Laurier, Ste-Foy, Québec G1V 4G2, Canada.

25. The authors wish to express their gratitude to Mme Louise C. Dussault and Mlle Nicole Beaudoin for their expert technical assistance and to Mme Michele Boissonneault for the preparation of this manuscript.

26. Dr. Pierre Coulombe is a Scholar from MRC.

27. This work is supported by MRC grant no. 5730 .

28. Received for publication April 9, 1981

29. Accepted for publication June 7, 1982. 